\title{
Pavel Sýkora
}

Janáčkova akademija za glasbo in upodabljajočo umetnost, Brno

Janáček Academy of Music and Performing Arts, Brno

\section{Monteverdi's Orfeo - Shakespeare's Hamlet: Polycentric composition as the effort to find order in the uncertain times}

\section{Monteverdijev Orfej - Shakespearov Hamlet: policentrična kompozicija kot poskus iskanja reda $v$ nemirnih časih}

Prejeto: 14. november 2018

Sprejeto: 1. marec 2019

Ključne besede: manierizem, renesansa, destrukcija, prelomljeni rituali, parlare disgiunto, sferično zrcalo, harmonija, gotovost, red, simetrija, policentrizem, paralelizmi

IZVLEČEK

Zelo učinkovit način reševanja kriz v obdobju manierizma je razrešitev v umetniški strukturi. Članek primerja težnje k policentričnemu načinu kompozicije dveh umetnikov, ki sta se rodila v 60. letih 16. stoletja - Claudio Monteverdi in William Shakespeare.
Received: $14^{\text {th }}$ November 2018

Accepted: $1^{\text {st }}$ March 2019

Keywords: Mannerism, Renaissance, destruction, broken rituals, parlare disgiunto, curved mirror, harmony, certainty, order, symmetry, polycentrism, parallelisms

\section{ABSTRACT}

Highly effective mode of solution to the crises in the Mannerist epoch is the solution in artistic structure. This article compares tendencies towards polycentric composition by two artists who were born in the 1560s - Claudio Monteverdi and William Shakespeare. 


\section{Mannerist destruction}

A term that repeatedly appears when Mannerism is being characterised is 'destruction'. Originally, it had a negative meaning, referring to the destruction of the Renaissance harmony, its artistic forms etc. Shakespeare depicted the destruction of the social order, for instance, in the opposition of Othello and Iago: the former representing the order's positive side, the latter its negation. The tragedy of Hamlet (c. 1600) introduces a more intricate situation. In the proverbial state of Denmark, everything seems to work harmoniously, the only disruptive element being the Prince. By disrupting the seemingly perfect order, however, Hamlet reveals its false essence. In other words, the aim of Hamlet's extravagant behaviour, including his (feigned) madness, is not to disintegrate the State; on the contrary, the protagonist strives for a solution of the critical situation. This is the way in which Mannerist art is perceived by Max Dvořák, who advocates its negative features, saying that its goal is a solution of the pressing spiritual questions for which the Renaissance did not have the answers. One of the effects of these questions' coming to surface was a disintegration of Renaissance forms and compositional techniques. ${ }^{1}$ Let us, therefore, compare from this aspect certain issues in Shakespeare's play and Monteverdi's first stage work.

Wylie Sypher maintains that the principal Mannerist dramatic form is tragicomedy. ${ }^{2}$ The tension between the tragic and the comic in expressing the human lot is one of Shakespeare's characteristic devices. Grave situations are often counterbalanced by their comical mirror images which relieve the tension. The relief, however, is only illusory as the mirror is curved or convex. ${ }^{3}$ The gravedigger scene in Hamlet (V.1) has this effect, parodying the famous soliloquy about being or not being. If Shakespeare calls the gravediggers 'clowns', a parallel suggests itself with the shepherds (Pastori) in Monteverdi's Orfeo (1607). Their excessive emotionality creates a contrast (a curved mirror) to Orpheus's deep sorrow upon learning about Eurydice's death. The cry of these 'buffoons' may seem unconvincing, even comical. On the one hand, they experience the good and the bad with the main hero; on the other, their reactions are unnaturally exaggerated. The sincere sorrow of the eponymous protagonist, devoid of grand theatrical gestures, thus becomes more apparent.

\section{Broken rituals}

One of the prominent features of Shakespeare's Hamlet is a breaking of rituals, especially the funeral ones: the funeral of Hamlet's father is desecrated by the hasty wedding of Gertrude and Claudius; Laertes's father is not properly buried, although he is

1 Max Dvořák, Kunstgeschichte als Geistesgeschichte: Studien zur abendländlischen Kunstentwicklung (München: R. Piper \& Co. Verlag, 1924), p. 221 etc.

2 Wylie Sypher, For Stages of Renaissance Style: Transformations in Art and Literature 1400-1700 (Garden City, NY: Doubleday \& Company, Inc., 1955), p. 122.

3 See Parmigianino, Self-portrait in a convex mirror (c. 1524); compare Gustav René Hocke, Die Welt als Labyrinth: Manier und Manie in der europäischen Kunst: Von 1520 bis 1650 und in der Gegenwart (Hamburg [i.e. Reinbek bei Hamburg]: Rowohlt, 1978), pp. 7-8. 
an important state official; in the 'mad scene' (IV.5), Ophelia distributes wedding flowers, which, in fact, announce her death. These broken rituals are the image of the destruction of the Danish state, which symbolises the collapse of the social order as such.

The subject matter of L'Orfeo is a wedding, or, rather, an interruption of a wedding ritual and its consequences. The wedding frame refers to Renaissance intermedi, staged, for instance, during the wedding celebrations of the Florentine house of Medici. Of these, the one particularly important for the commencing genre of opera is La Pellegrina (The Pilgrim Woman, 1589), to the composition of which the members of the Camerata contributed. It is not without interest that the orchestra included Alessandro Striggio as a violist, the later librettist of L'Orfeo. The first complete production of an opera, Peri's Euridice, also took place during a court wedding (October 6, 1600, in Palazzo Pitti).

Renaissance wedding ceremonies were usually connected with comedies, which tended to end with a wedding and wedding feast, accompanied by dance as a confirmation of the harmony between the natural and social order. ${ }^{4}$ This message can also be attributed to the final Ballo del Granduca at the end of the sixth intermedio during the 1589 celebration. A prototype is established of a new genre - a combination of singing and dancing in an elaborate choreography.

The first act of Monteverdi's Orfeo is permeated with nuptial dancing and singing, which intensify in the following act, until the announcement of Eurydice's death, which marks a key dramatic turning point, followed by a significant change in the musical texture. From now on, the drama is closer to a tragedy, in which the hero descents into Hades to ask Pluto (Plutone) for his, Orpheus's, beloved bride. He succeeds; however, when he disobeys the order not to look behind on the way back, he loses his lady forever. The situation becomes unsolvable. In the final act, Orpheus wanders alone through the waste Thracian landscape, lamenting. The last words of each strophe are repeated by an echo (Eco), which, unlike in the concerto Audi coelum from Monteverdi's Marian Vespers (Vesperae Beatae Mariae Virginis, 1610), does not give any hope. The crisis is resolved by Orpheus's divine father Apollo, who, as a deux ex machina, elevates his son to the heavens. As if by means of a cinematic cut, the atmosphere of the beginning of the work is restored. Shepherds and nymphs enter the scene, sing joyfully and dance moresca. Their performance has a cathartic effect and could be understood as a triumph over death.

The aforementioned overcoming of the crisis is included in the printed sheet music of $1609 .^{5}$ It is effective, but, from the dramatic point of view, illogical, since it does not offer a solution of the work's most crucial problem: on the one hand, the hero is elevated to the sphere of demigods; on the other, he loses his wife forever. Considering this, the joyfulness of the shepherds might seem histrionic and unconvincing, which, however, as has already been mentioned, is a distinctive trait of these characters. The original printed libretto of $1607^{6}$ is at odds with this score. In the spirit of Ovid's Metamorphoses (X-XI), Striggio's main source (the scenes in the underworld are based on

4 Compare Martin Hilský, Shakespearův Hamlet [Shakespeare's Hamlet], in: William Shakespeare, Hamlet, dánský princ [Hamlet, the Prince of DenmarkJ (Brno: Atlantis, 2011), p. 36.

5 Ed. Ricciardo Amadino, Venice, 1609.

6 Ed. Francesco Osanna, Mantua, 1607. 
the fourth book of Virgil's Georgics), the scene is stormed by the furious Maenads (Baccante) to stone the poor singer. This cruel fate is, however, paradoxically necessary for the happy ending of the drama. Neither in classical mythology, nor in Christianity was death understood as the absolute, painful end. Orpheus has to die so that he could meet his Eurydice in the underworld and live with her forever. From this perspective, even this ending could have a cathartic effect, at least in music (which, however - unlike the libretto - does not survive).

Why was the work's finale altered in this manner? A theory suggests itself about an intervention of the Duke of Mantua, who may not have been happy with the original form. Although L'Orfeo was not designed for wedding celebrations (the production took place during the carnival), a praising of the House of Gonzaga was expected (similarly to the 1589 intermedio, in which the gods pay homage to the City of Florence and its court). An undeformed (unconvex) mirror image was thus created of the introductory Prologue, in which the personified Music solemnly addresses its audience: 'Dal mio Permesso amato a voi ne vegno, / incliti eroi, sangue gentil de regi.' Promotion of aristocracy was certainly the most important factor; the theophany of Apollo can thus be understood as a glorification of the Duke. The Furies of the original version could hardly serve this purpose; they are, however, perfectly appropriate for carnival frenzy. In a defence of the Bacchian scene, it should be noted that Striggio's libretto does not contain any violence (as opposed to some modern productions of the piece which apparently revel in it $^{7}$ ).

In the context of the thesis about the destruction of the ceremony, the original ending with the Maenads might be understood as a case of ironisation, or parodying, of the pastoral, which was in the late $16^{\text {th }}$ and early $17^{\text {th }}$ centuries fashionable and excessively employed. Nino Pirrotta maintains that the original solution would have even ridiculed the courtly life. ${ }^{8}$ In any respect, the older version creates a deformed image of the work's beginning. The question remains, however, whether the contrast between the wedding and the underworld scenes should be understood within the frame of the Baroque balance of the opposites or we should view these worlds through the prism of the Mannerist destruction and ironisation. In the second case, the spirits of the underworld would appear to be a curved mirror image of the nymphs and shepherds: the former would thus, similarly to the gravediggers in Hamlet, emphasize the latter's real character. The ire of the Furies at the end might evoke Ophelia's madness. In the 'mad scene' (IV.5), instead of getting married, she hands over wild flowers to everyone on the stage, resembling the 'furious' ending of L'Orfeo, but also, for instance, The Rake's Progress by Igor Stravinsky (1951), which is also based on the ironisation of the pastoral in early opera.

We can, however, view the other, 'optimistic', finale from the perspective of ironisation and parody as well. As it radically simplifies the dramatic situation upon the intervention of the God, it necessarily contains elements of a caricature. It is obvious that the 'furious' theme has not been entirely suppressed. Even if saw this solution in the

7 See e.g. Claudio Monteverdi, L'Orfeo [DVD] (Dynamic srl, Genova, 2005).

8 Nino Pirrotta, "Monteverdi and the Problems of Opera," in: Nino Pirrotta. Music and Culture in Italy from the Middle Ages to the Baroque: A Collection of Essays (Cambridge: Harvard University Press, 1984), pp. 244-245. 
context of the vaudeville finale (which appeared somewhat later), the composer still had to deal with the story which was, in both versions of the opera, unfinished at that stage and abruptly ended, similarly to the story of Hamlet.

\section{Parlare disgiunto}

From his fourth book of madrigals (printed 1603) onwards, Claudio Monteverdi ceased to set verse to music as a single melodic arch and began to break the melodic flow into individual motifs. By doing this, he represents a new approach to the text on the part of the composers in the Mannerist epoch. While the Renaissance madrigalists respected the unity of verse and tried to emphasise important words by means of rhetorical figures, Monteverdi picks the 'key words', which are emotionally charged. If such a word dominates a longer musical unit, the poetic source is necessarily broken into distinct parts. While the members of the Camerata made use of this technique in recitative, Monteverdi employs it in polyphonic music as well, both secular (madrigals) and spiritual (Vesperae Beatae Mariae Virginis and certain masses). In Mannerism, emphasised emotionality replaced realistic descriptiveness; as Gustav René Hocke puts it, the Renaissance imitazione della natura had morphed into imitazione fantastica. ${ }^{9}$ Passion is more important than the form, which adapts to the former.

Because of their tight link to text set in music (according to the rule of imitazione delle parole), these tendencies in music are closely connected with the literature of the period. Sypher calls this phenomenon an 'isolated phrase': each of the movement is more or less isolated and taken out of context and the narrative is interrupted by splits and irregularities, thus losing its coherence. ${ }^{10}$ This is just a step from a collapse of the macrostructure of the work. Torquato Tasso's epic Gerusalemme Liberata (The Liberation of Jerusalem, 1575) did not follow the Aristotelian rules - unlike Dante's La Divina Commedia (The Divine Comedy, 1307-21), the formal and spiritual model for the Italian epic writers of subsequent generations - dissolves into separate episodes which overshadow the whole. Tasso himself calls this technique parlare disgiunto (disjointed speech); Galileo Galilei talks about 'assembling a mosaic' (Considerazioni al Tasso, I).

Monteverdi picks highly emotional texts for his adaptation. He likes extreme positions - permanent suspense between sadness and joy. One of the emotions which he emphasises is ferocity, grading into madness, for which he defined a so-called agitated style, which he calls genere concitato. An expression of this aesthetic attitude is, for instance, the character of Clorinda in his Il Combattimento di Tancredi et Clorin$d a$ (The Combat of Tancred and Clorinda, 1624). The heroine, who clashes with her loathed rival, responds to his words angrily, even hysterically (feroce). Her screaming deforms the original verse structure of Tasso's poem, which, on the one hand, contains

9 Gustav René Hocke, Die Welt als Labyrinth: Manier und Manie in der europäischen Kunst: Von 1520 bis 1650 und in der Gegenwart (Hamburg [i.e. Reinbek bei Hamburg]: Rowohlt, 1978), p. 45. Gustav René Hocke, Manierismus in der Literatur: Sprach-Alchimie und esoterische Kombinationskunst: Beiträge zur vergleichenden europäischen Literaturgeschichte (Hamburg [i.e. Reinbek bei Hamburg]: Rowohlt, 1959), pp. 14, 136 etc.

10 Compare Wylie Sypher, For Stages of Renaissance Style: Transformations in Art and Literature 1400-1700 (Garden City, NY: Doubleday \& Company, Inc., 1955), pp. 175-176. 
numerous asymmetries, but, on the other, is at least framed in regular octaves. A breakdown of verse into isolated statements takes place in the dying girl singing as well. The deadly wounded warrior cannot talk - the composer interrupts her text with pauses. ${ }^{11}$

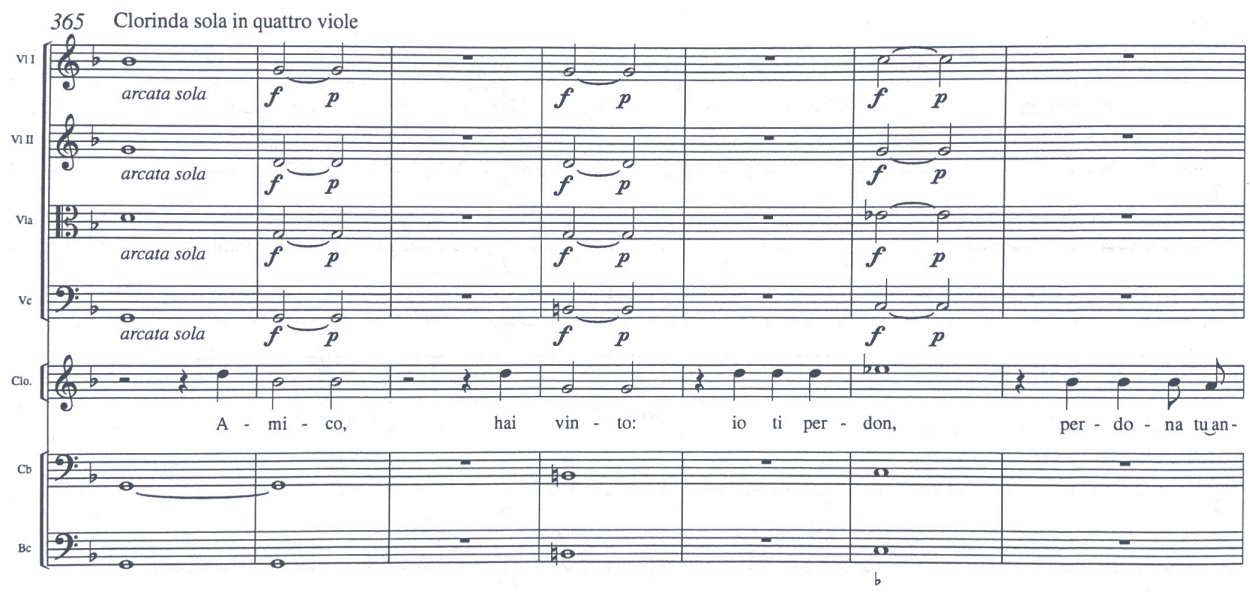

Example 1: Il Combattimento di Tancredi et Clorinda, bars 365-371.

Ophelia, too, although for different reasons than Clorinda, sinks into the state of madness. Her speech in the 'mad scene' (IV. 5) is broken into fragments of songs, resembling - according to Martin Hilský - a bouquet of gathered wild flowers. ${ }^{12}$ Her speech, however, can also be characterised less poetically as chaotic and disharmonic. On the other hand, these fragments of songs are permeated with motifs from ancient ballads of death, burial, and the betrayed and beaten love. ${ }^{13}$ The final effect is not, therefore, a total disharmony as in Clorinda's scream; a closer parallel would be the asylum scene in Stravinsky's The Rake's Progress, in which Ann sings a ballad-lullaby for the poor Tom. It should, however, also be noted that even in Clorinda's parlare disgiunto is pervaded with an echo of a higher order: in the last moments of her life, the heroine fastens her thoughts to baptism and words 'faith', 'love', and 'hope' (fé, carità, speme, measures 355-57) enter her intermittent speech, lending her singing the certainty of faith.

In Hamlet, Shakespeare does not rely on a single composition technique, a single poetic form. It could be argued that every time when the characters sink into uncertainty and anxiety, the regular line - blank verse - grades into prose. The Renaissance sense of order and symmetry is at all times confronted with asymmetrical elements, which resembles the technique of recitative, in which regular verses, due to the way in which they are set in music, make an impression of prose.

11 Compare Pavel Sýkora, Claudio Monteverdi: The Combat of Tancred and Clorinda: Between Mannerism and the Baroque (Prague: KLP, 2017), pp. 82, 125-126.

12 Compare Martin Hilský, "Shakespearův Hamlet" [Shakespeare's Hamlet], in: William Shakespeare: Hamlet, dánský princ [Hamlet, the Prince of Denmark] (Brno: Atlantis, 2011), p. 81.

13 Ibid., p. 82. 
A character in which can be observed the Shakespearian changing of emotions - of happiness, sadness, uncertainty, and even despair - is the eponymous hero of Monteverdi's first opus in genere rappresentativo (1607). This manifests itself both in the macrostructure of the work and the central aria, in which Orpheus tries to overpower Charon by means of his singing ('Possente spirto e formidabil nume', Act III). For Orpheus's key moment in the underworld, Striggio (who, in his libretto, oscilates between various poetic forms $)^{14}$ opts for a terzina, a strophe from Dante's The Divine Comedy. Dante's poem is referred to even earlier in the work, in the singing part of Hope (Speranza) by means of a verbatim quotation from the epic: 'Lasciate ogni speranza, voi ch' entrate'. ${ }^{15}$ The composer emphasises the inscription over the gate to Hell by figure of a hyperbaton - he repeats the line a second higher, thus enriching the structure of the singing part, which has a prosaic character - that is, it is without a repetition of the text.

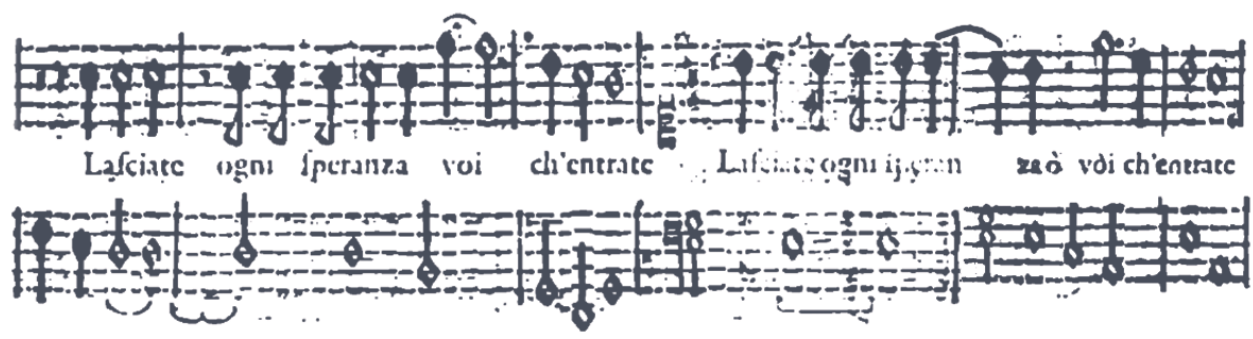

Example 2: L'Orfeo, Act III, Speranza.

In Orpheus's aria, Monteverdi markedly separates individual strophes, which he emphasises after the first three strophes by means of echoic ritornellos of solo instruments - each strophe is assigned a different instrumental register: 2 violins, 2 cornetts, and a harp. The said instruments also isolate the individual verses - and in the first verses of each strophe, both hemistichs:

Possente spirto [2 violini] e formidabil nume, [2 violini]

senza cui far passaggio a l'altra riva [2 violini]

alma da corpo sciolta in van presume. [Ritornello]

Non vivo io, no, [2 cornetti] che poi di vita è priva [2 cornetti]

mia cara sposa, il cor non è piu meco, [2 cornetti]

e senza cor com'esser può ch'io viva? [Ritornello]

etc.

The fourth strophe, in which the hero introduces himself by the simplest words, 'Orfeo son io, che d'Euridice i passi', is enlivened by a group of strings. The singing itself, however, is significantly disrupted by extreme virtuosity, which has its own logic: after

14 Compare Tim Carter, Monteverdi's Musical Theatre (New Haven - London: Yale University Press, 2002), pp. 52-57.

15 Inferno, III.9. 
all, Orpheus is a singer who fights with his very own weapon. The technical ornaments, on the one hand, emphasise the individual words, but, on the other, blur the contours of the whole. Virtuosity has thus a similar effect as the use of recitative in other places. The singing equilibristics, moreover, can induce the fear and anxiety of the work's protagonist.

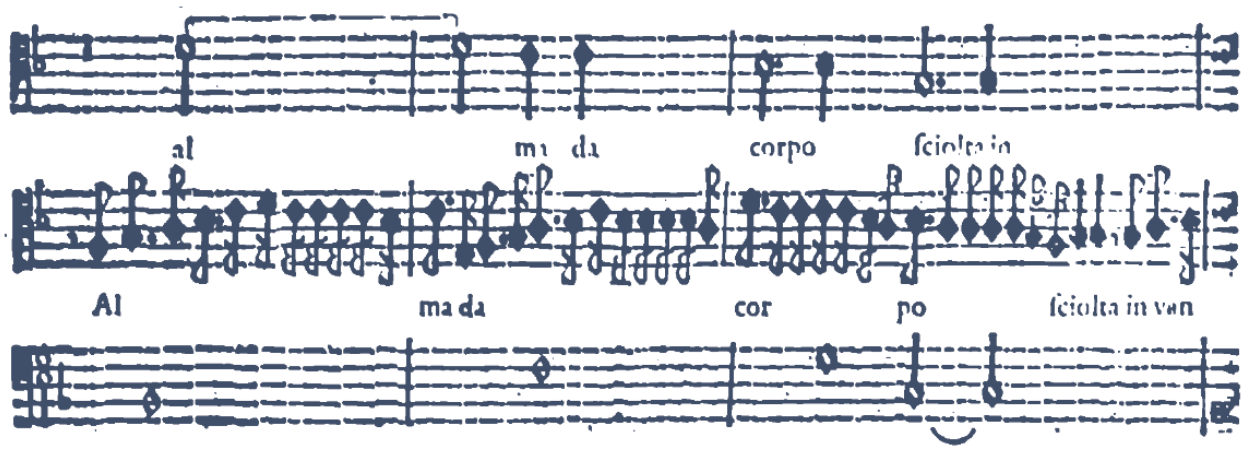

Example 3: L'Orfeo, Act III, Possente spirto (example of vocal virtuosity).

\section{Polycentric composition}

According to Sypher, the Renaissance period (the $15^{\text {th }}$ and $16^{\text {th }}$ centuries) was marked by the artists' effort to find a new order of composition which would lend their world a unity. They found the solution in the golden ratio, ideal proportions, or a complex capture of space and action from one firm point. At the end of the epoch, however, it became obvious that the mere experimenting had not brought any satisfactory result: 'The renaissance harmony was based upon an artificial and enforced unity, which often raised more problems than it solved. ${ }^{16}$ In a similar manner, Dvořák maintains that the Renaissance focused too much on the formal aspects of a work of art, forgetting to take into consideration spiritual needs of a man. These surfaced in the Mannerist period, ${ }^{17}$ leading to the disintegration of art into many styles and the appearance of new forms.

A kind of Mannerist 'polystyle' is discernible in certain stage and church works by Monteverdi from his Mantua period (especially in the 1610s). In order to express the tragedy of Orpheus, the composer combined various devices that were current at the time: apart from the monody with instrumental accompaniment, which had appeared not long before, he also employed choirs, which drew from the Renaissance madrigal texture, connected, however, with the new thorough-bass technique; one of the new

16 Wylie Sypher, For Stages of Renaissance Style: Transformations in Art and Literature 1400-1700 (Garden City, NY: Doubleday \& Company, Inc., 1955), p. 33.

17 Max Dvořák, Kunstgeschichte als Geistesgeschichte: Studien zur abendländlischen Kunstentwicklung (München: R. Piper \& Co. Verlag, 1924), pp. 220, 221, 257 etc. 
elements employed by Monteverdi is duets; Orpheus's song 'Possente spirto' may be considered the first real aria in the history of opera. Instrumental music creates an unseen dramatic effect, chiefly by means of ritornellos as a unifying dramatic element. In the Vesperae Beatae Mariae Virginis, the Christian rite is amplified by means of three distinct styles: choral antiphons, polyphonic psalms in stile antico, and solo motets. The traditional forms by themselves were obviously not sufficient to capture the new world order. In this respect, Orpheus can be understood not only as a mythological hero, but also a contemporary protagonist who struggles with an ultimately unsolvable situation: to return his dead wife to this world. A similar blending of Renaissance and Baroque elements is discernible in Shakespeare. A question suggests itself of what (apart from the basic, underlying idea) is a formal, unifying element of these works if they are marked by a disintegration of structure and use of different styles.

The uncertainty of the Mannerist epoch could be, on the artistic level, solved in two ways: firstly by simplifying the problem - an example of this might be the Baroque descent of the heavens to the earch, that is, the implementation of the hic et nunc certainties; secondly, by making the unanswered questions even more acute. In Hamlet, Shakespeare opted for the latter option. This specific play is mentioned here because, out of Shakespeare's great tragedies, it has the most relaxed composition. At the first sight, everything seems chaotic and confused. Nothing is straightforward, the individual plots remain without proper endings and no question is answered. All the time, the story is being interrupted. The final effect is one of improvisation and chance. Upon a closer inspection of the structure of the play, however, it becomes apparent that these 'deffects' are result of the author's careful design. ${ }^{18}$ The method of interrupting the story in order to strengthen the dramatic effect was employed by Monteverdi in Il Combattimento di Tancredi et Clorinda, where, in the first battle scene, he included the epic account of Testo (bars 88-133), which magnificiently - even bombastically describes to the audience the fierce fight between the two heroes. ${ }^{19}$

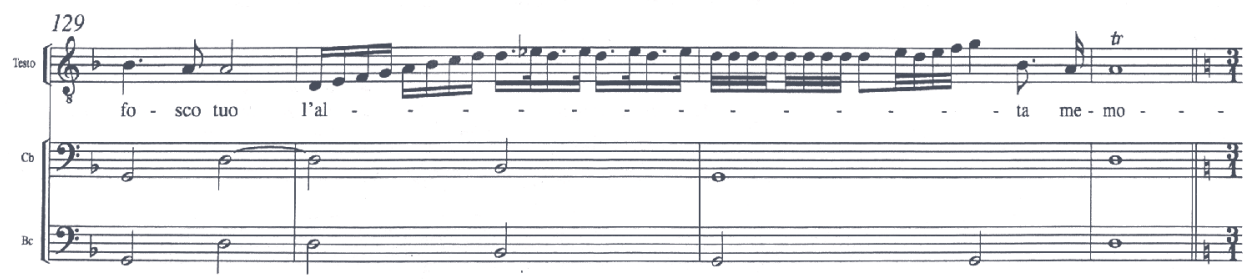

Example 4: Il Combattimento di Tancredi et Clorinda, bars 129-132.

A similar effect of the arrested time can be observed later in The St. Matthew Passion by Johann Sebastian Bach (BWV 244, 1727, ${ }^{2} 1736$ ): in the scene before Pilate, the composer interrupts the cry of the crowd 'Laß ihn kreuzigen' by inserting a choral, a recitative

18 Compare Martin Hilský, "Shakespearův Hamlet" [Shakespeare's Hamlet], in: William Shakespeare: Hamlet, dánský princ [Hamlet, the Prince of Denmark] (Brno: Atlantis, 2011), p. 43.

19 Compare Pavel Sýkora, Claudio Monteverdi: The Combat of Tancred and Clorinda: Between Mannerism and the Baroque (Prague: KLP, 2017), pp. 78, 97-98. 
and the aria 'Aus Liebe will mein Heiland sterben' (NBA $\left.45^{\mathrm{b}}-50^{\mathrm{b}}\right)$.

The design of Shakespeare's Hamlet is based on parallelisms. It has five acts, the formal centre being Act III, around which Acts II and IV symetrically extend. Further from the centre, Acts I and V are situated. The individual acts revolve around the centre in a similar manner as the planets revolve around the Sun. The formal base of the play is thus an idea of a hierarchised cosmic order, in which - in the spirit of the harmony of the spheres - the mundane order corresponds to the cosmic order, the divine one. The parallels could also be found between the individual scenes, for instance I.3 (Ophelia's first appearance on the stage) and IV.7, the third last scene (Gertrude announces Ophelia's death). The five acts of Hamlet, comprising twenty-one scenes, are thus like 'ripples on the water surface, spreading from one centre'. ${ }^{20}$ At the centre of the play is the play-withing-the-play, which is not a mere intermezzo but has a crucial significance for the story.

The work's symmetry is, however, not ideal in the spirit of the Renaissance. The mirror images are curved, even flipped. They do not represent a perfect mimesis, described in the Renaissance as a theory of mirrors, but a flipped symmetry, ${ }^{21}$ or, a curved mirror. Ptolemy's ideal cosmos, in which the planets' orbits are perfect circles, is deformed into Kepler's elliptic universe, in which the planets come closer (perihelium) and further (aphelium) to or from the Sun. Furthermore, Hamlet has two centres: the play-within-the-play (III.2), or, more accurately, the moment when Polonius interrupts the production and Claudius asks for some light (III.2.270-73); and the 'closet scene' (III.4), during which Hamlet makes his mother confess her guilt (III.4.88-91).

Monteverdi's Orfeo, too, contains a structure based on parallelisms. The work's hero resembles a character from a classical tragedy, controlled by a fatalistic principle: his existential situation does not have any solution and he cannot bring his dead wife back to this world; the more effort he makes, the more he rides for a fall. Let us, however, bear in mind that L'Orfeo, on the one hand, formally draws on the tragic structure, having a Prologue and five acts, but the basis for its design itself is rather the tradition of Renaissance pastoral plays. The final catharsis is replaced by a simplified solution, the Euripidean principle of the deus ex machina, which was extremely popular in the Baroque theatre. The whole, however, shows a dramatic unity, which is - besides other expressive devices - based on numerous parallels, which, nevertheless, never create a perfect symmetry.

The wedding scenes find their reverse mirror images in the scenes filled with sorrow and despair. The composer underscores this by means of contrast in all the aspects of the musical texture. The acts which are furthest apart, that is, the first and the fifth, create the greatest opposites: the former is pervaded with wedding joy; the latter, with Orpheus's cry. At the beginning of the work, the scene is filled with nearly the entire cast of characters, including Eurydice, who is otherwise physically absent most of the time; in the final act, however, a lonely individual is to be found. It is at the very end of the drama that the atmosphere of its beginning is resored, which creates a formal

20 Martin Hilský, "Shakespearův Hamlet" [Shakespeare's Hamlet], in: William Shakespeare. Hamlet, dánský princ [Hamlet, the Prince of Denmark] (Brno: Atlantis, 2011), p. 41.

21 Compare Ibid.. 
frame of the story.

The parallel between the second and fourth acts is more complicated and less symmetrical. The first part of Act II is marked with an apex of the wedding joy, in which Orpheus participates. Towards the end of the fourth act, Orpheus is given back his lost bride and the optimistic mood is restored. His joyful singing, 'Qual onor di te fia degno', which he sings when leading his wife out from the underworld, as if continued the song 'Vi ricorda, o boschi ombrosi' from the second act.

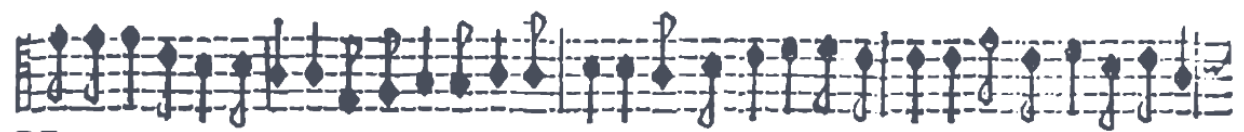

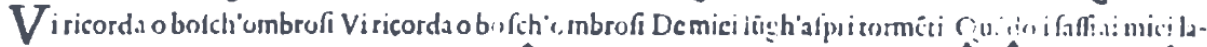

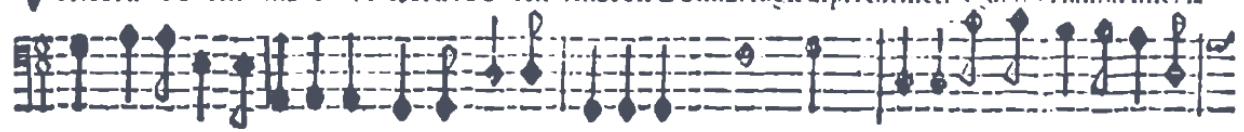

Example 5: L'Orfeo, Act II, Vi ricorda, o boschi ombrosi.

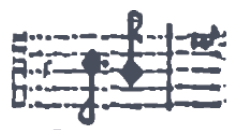

Viulme.

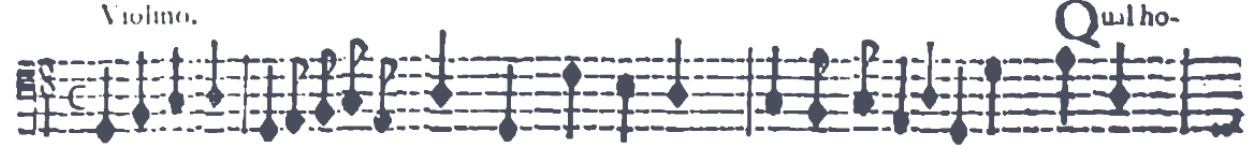
R I I UK: : I L ().

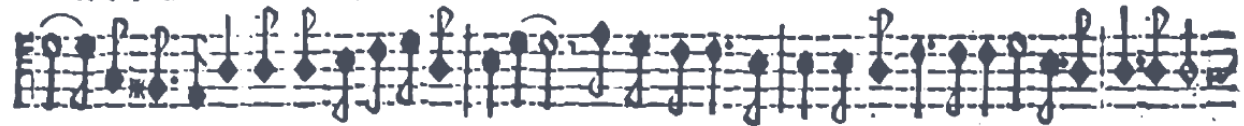
nor di te tildigno Mracctronnipotente Shainel Tartarcu regno Pjegar potutoogni indurata men-

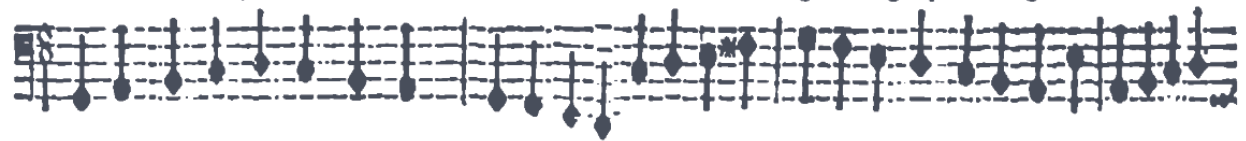

Example 6: L'Orfeo, Act IV, Qual onor di te fia degno.

The second half of Act II is pervaded with shock from the death of the beloved Eurydice and crying over the loss. The opening of Act IV is still marked by grief, but also by hope: Proserpine is trying to mollify her husband, the ruler of the underworld. This system of reverse images is 'distorted' ('curved') by the end of the fourth act, when Orpheus does not observe the terms and loses his beloved again, this time, most probably, forever.

The sad farewell to the bride anticipates the final act. As if the dramatic turning point of Act II took place in a reduced form here. Back then, however, Orpheus was not alone in his grief. It is not so much important that the playing space was filled with 
lamentations of the shepherds (whose grief did not necessarily have to be authentic) - the nymph Silvia assumed Orpheus's grief and thus allowed the poor groom to bear his fate without pompous gestures. In Act V, in contrast, it is only an echo (Eco), which responds to Orpheus's crying.

Partial parallels can also be found in the work's microstructure, that is, the individual scenes or music and poetic forms. Let us mention Orpheus's declaration of love, 'Rosa del ciel, vita del mondo', which, in the context of a buoyant celebration, strikes the audience with its sincere simplicity and decorum. Eurydice is moved by Orpheus's singing and promises to stay with her husband in a union filled with love: 'ma teco stassi in compagnia d'Amore'.

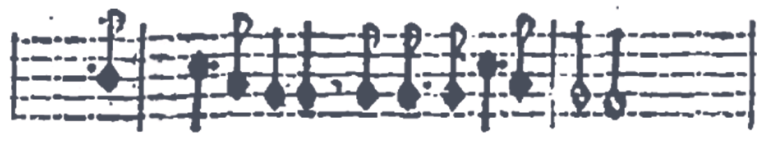

Ma teco fuff incopasnis d'imore

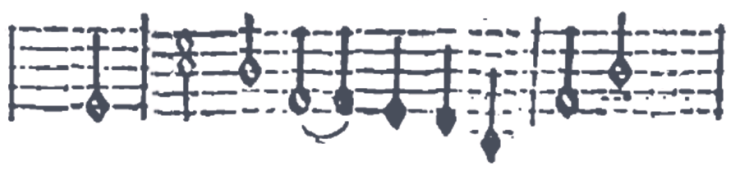

Example 7: L'Orfeo, Act I, Euridice, Ma teco stassi in compagnia d'Amore.

When, later on, the poor groom is trying to recollect himself from Eurydice's death, he decides to stay with her even in death, which he expresses by means of a reversed mirror image of her statement: 'Rimarrò teco in compagnia di morte'.

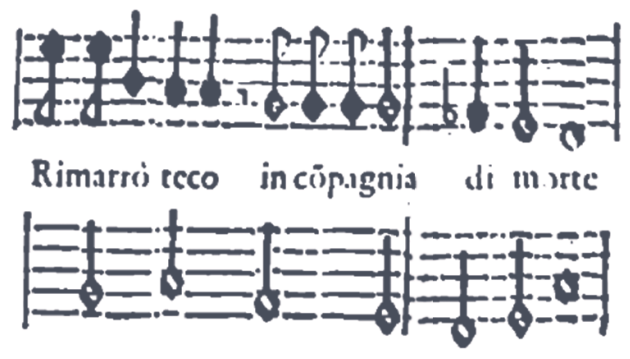

Example 8: L'Orfeo, Act II, Orfeo, Rimarrò teco in compagnia di morte.

In Act III, the very centre of the work, the composer inserted Orpheus's aria 'Possente spirto'. This passage is a celebration of music and its mighty effect. Orpheus's singing is capable of overpowering even brutal force, as Lorenzo explains to Jessica in The Merchant of Venice (c. 1596): 
Therefore the poet

Did feign that Orpheus drew trees, stones and floods,

Since naught so stockish, hard, and full of rage,

But music for the time doth change his nature[.]

$($ V.1.79-82) 22

What character of music is this? Having set off to Hades to find his beloved Eurydice, Orpheus fights an uneven fight with Charon, who can neither be overpowered by force nor moved with pity. The gatekeeper of the underworld knows no mercy. The hero of Monteverdi's favola in musica, therefore, lulls Charon (Caronte) to sleep by his singing. A similar power of Orphic music is described in Shakespeare's Henry VIII (c. 1612): 'Killing care and grief of heart / Fall asleep or, hearing, die' (III.1.13-14). ${ }^{23}$ In this context, a comparison suggests itself between this motif and Manfred F. Bukofzer's description of consorts of viols. For their emotionless and abstract sound, he characterises them as 'still music'. ${ }^{24}$

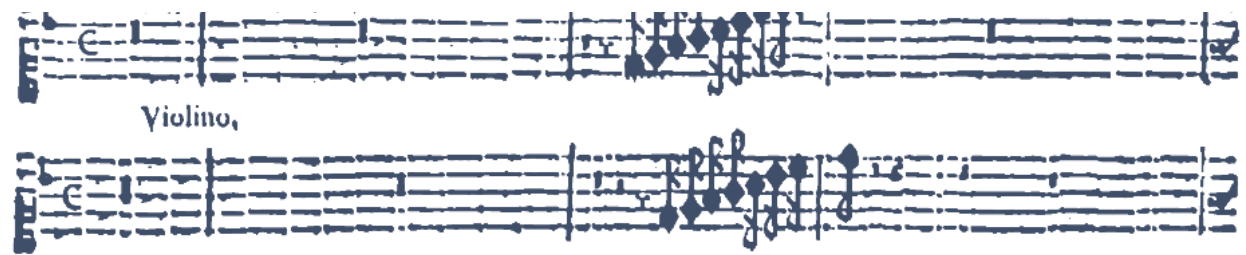

Violino.

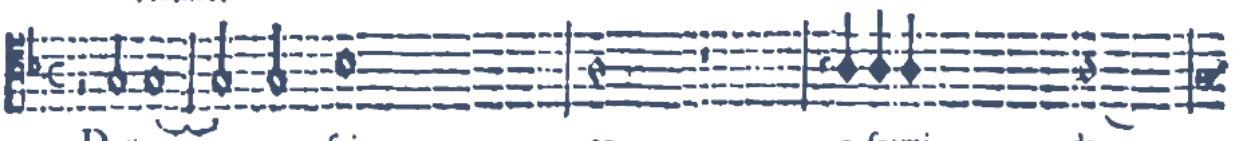
P. illin

to

c formi

da
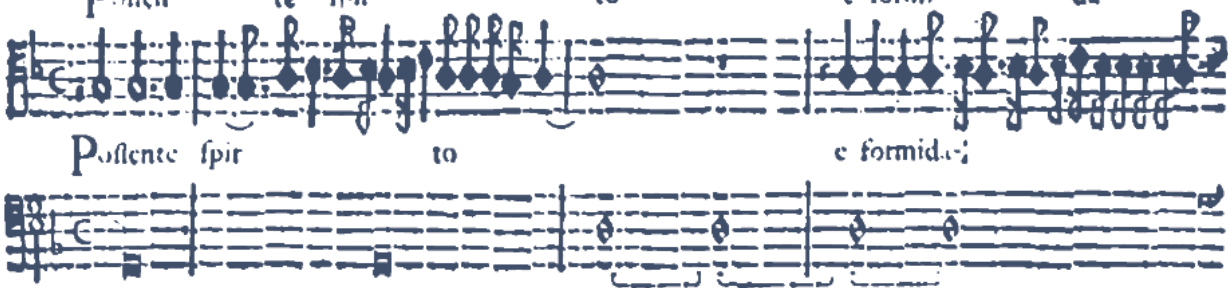

Example 9: L'Orfeo, Act III, Possente spirto (the beginning).

Considering the fact that the aria is sung by a demigod (according to mythology, Orpheus was a son of Apollo), this part - which is dominated not only by solo singing, but also by solo instruments - can also be regarded as a defence and elevation of art

22 All quotations from Shakespeare are taken from William Shakespeare, The Arden Shakespeare Complete Works, rev. ed., ed. R. Proudfoot, A. Thompson and D. S. Kastan (London: Arden Shakespeare, 2011).

23 Compare Tim Carter, Monteverdi's Musical Theatre (New Haven - London: Yale University Press, 2002), p. 116.

24 Manfred F. Bukofzer, Music in the Baroque Era: From Monteverdi to Bach (New York: W. W. Norton and Company, 1947), p. 74 . 
in the spirit of Renaissance deism. Orpheus's singing to Charon is virtuosic, but also permeated with deep emotions. In terms of its sincere sensitivity, it creates a parallel to the entrance of Messaggera in the second part of the previous act; the nymph Silvia inappropriately accepts the guilt for the death of her ward, giving an account of how the tragic event happened: 'Ma io, ch'in questa lingua / ho portato il coltello' etc.

In L'Orfeo, too, just as in Hamlet, two centres could be found. They are linked by means of deep grief; however, they are not identical in terms of their musical structure: only in Orpheus's aria effective concertante virtuosity can be heard.

The design by means of parallelisms and polycentrism lends the works unity even if, on the ideological level, uncertainty and a lack of answers to pressing questions can be discerned. In Monteverdi's Orfeo, the supreme unifying element is instrumental ritornellos. The fact that this element occurs in an unaltered form in various, often contrasting situations lends the work an order and contributes to its dramatic effect. This composition type may be understood as an antithesis to the Renaissance idea of linear development, which promised to solve all the problems, without, however, being capable to accomplish its aims with the chosen methods.

After the collapse of the Renaissance world-image, based on harmony, Man found himself in the Universe which he no longer understood. Not only do Hamlet's questions remain unanswered; they invoke new ones. Instead of giving the hero guidance on how to act, the Ghost of Shakespeare's tragedy, similarly to the characters of the witnesses of events in Tintoretto's pictures, he provides Hamlet with grounds for uncertainty and creates new problems for him. The character of Testo from Monteverdi's Combattimento di Tancredi et Clorinda knows the upcoming events, which he makes effective use of to raise suspense. Even Musica in the prologue to L'Orfeo only hints at the story of the favola, without, however, finishing it. It is noteworthy that ghosts in the Elizabethan theatre often served as prologues. A similar case is the 'voice from on high' in Monteverdi's concerto Audi coelum (Hear, O Heaven) from Vesperae Beatae Mariae Virginis. A lonely human soul cries to the heavens its questions, which already include answers: 'Audi, coelum, verba mea, / plena desiderio et perfusa gaudio' (Hear, O Heaven, my words, / Full of longing, and steeped in joy). The enquirer, in a joyful hope, enlists the qualities of her whose name he desires to hear: consurgens ut Aurora rutilat (rising, she shines like the dawn), pulchra ut Luna (beautiful like Luna), electa ut sol (chosen like the Sun) etc. The heavens do not let the enquirer down: the space is filled with the sound of the Virgin Mary's name, proving Man with the desired assurance. In terms of the compositional elements, however, the situation is not that straightforward. The answer is based on the word which is homonymous to the last word of the question: maria (the plural from of the 'sea') - Maria (the name Mary) (this is an example of the rhetorical figure called annominatio). The answer thus becomes an echo, rendering the heavens as a mere illusion, ${ }^{25}$ similar to Hamlet's uncertainty whether the Ghost actually exists. The fine art of the period was fond of toying with

25 Compare Pavel Sýkora, Claudio Monteverdi: The Combat of Tancred and Clorinda: Between Mannerism and the Baroque (Prague: KLP, 2017), pp. 48-52. 'Quae est ista, quae consurgens ut Aurora rutilat? Píseň písní v Monteverdiho Nešporách z roku 1610' ['Quae est ista, quae consurgens ut Aurora rutilat? Song of Songs in Monteverdi's Vespers of 1610']. Opus musicum (2014), no. 3, pp. 6-29. 
illusions, leading to the primary certainty of an order quickly becoming an uncertainty which only deepened the previous state of desperation.

Monteverdi's Orpheus certainly heard the voice of his God-Father. The symbiosis of the two is confirmed in their virtuosic duet. The divine singer, however, is not joyful; he is rather disappointed. To him, apotheosis signifies eternal separation from his beloved Eurydice. After all, he has expressed his dissatisfaction with the heavens by means of the curse 'Stelle ingiuriose'. Searching for eternal and present certainties, the hic et nunc ones, requires a much bigger effort than a simple transposition of heaven to the earth, which takes place, for instance, in Cavalieri's Rappresentazione di Anima, et di Corpo (Representation of the Soul and the Body, Rome 1600), an official Jesuit play which opens the era of the art of the early Baroque.

It is also worth noting that the compositing technique of Shakespeare's Hamlet has also parallels in certain composers of the $20^{\text {th }}$ century, who rejected the line of compositions 'focused on the finale'. This line was characteristic of a significant number of composers of the previous century, peaking in certain works of the late romantics. It is significant that composers of the avant-garde after the First World War, such as Igor Stravinsky, Béla Bartók, Bohuslav Martinů, Paul Hindemith and others, often found inspiration in the technique of Bach's Brandenburg Concertos (BWV 1046-1051; 1721) - preferring not the final effect, but joy from any piece of the composition. The spiritual world of Bach's compositions is different from the world of the Mannerist epoch. Hamlet's hesitation is replaced by a certainty of a higher, unquestionable celestial order. This might be why Stravinsky employs the principle of the polycentric form, based on the asymmetric-symmetric parallelism, ${ }^{26}$ chiefly in his late works. They are linked with the era of the Renaissance not only by means of the technique of ricercar, but also by a tendency to continually disrupt (Renaissance) symmetry. Instead of a direct perspective, in which the world is seen from a single firm point, they opt for a reversed, polycentric perspective: a phenomenon is observed from various angles. It is not a coincidence that this artistic approach to the search for certainty appeared after the Second World War - in a period marked by grief over the loss of certainties, similar to the period of Monteverdi and Shakespeare.

\section{POVZETEK}

Za obdobje manierizma je značilno, da je porušilo renesančni red sveta. Podobno se je tudi umetnost tega obdobja razdelila v več različnih gibanj: nek problem je prikazan iz - pogosto nasprotujočih si - zornih kotov, saj enoznačen pogled ne nudi zadovoljive rešitve. Takšna rešitev je posledica medsebojnih napetosti in asimetrij. Problem je zastavljen in s pomočjo igre nasprotij stopnjevan do točke nevzdržne napetosti, ki lahko ima katarzični učinek. Dotična študija se osredinja na vzporednice med formalno strukturo Shakespearjevega Hamleta in Monteverdijevega Orfeja. Obe drami - Monteverdijeva favola in musica in Shakespearjeva tragedija - delita strukturne elemente. Ob tragikomičnosti, prekinitvama med poroko ali aposiopezi oz. prekinjenem govoru (parlare disgiunto) lahko opazimo tudi dve emocionalni središči in asimetričen paralelizem med posameznimi scenami.

26 Druskin calls this principle ‘dissymetry'. Compare Michail Druskin, Igor Stravinsky: His Personality, Works and Views (Cambridge: Cambridge University Press, 1983). 